\title{
A MODEL FOR THE ACCURATE ESTIMATION OF METHANE EMISSIONS IN LANDFILLS
}

\author{
R. M. Balogun-Adeleye ${ }^{1, *}$, E. O. Longe ${ }^{2}$ and K. O. Aiyesimoju ${ }^{3}$

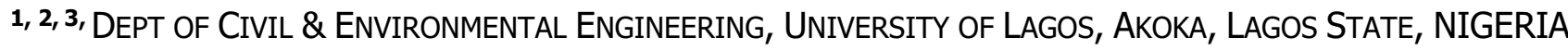 \\ E-mail addresses: ${ }^{1}$ rahmatmojisola@yahoo.com, ${ }^{2}$ dapolonge@yahoo.co.uk, \\ 3 kaiyesimoju@unilag.edu.ng
}

\begin{abstract}
Landfills are one of the major sources of methane $\left(\mathrm{CH}_{4}\right)$ emissions. Prediction of $\mathrm{CH}_{4}$ emissions from landfills is important in estimating power generation potential and greenhouse gas (GHG) emissions from landfills. The most widely used landfill gas (LFG) models developed based on the first order decay (FOD) reaction do not take into account changing waste composition and landfill site conditions in methane estimations. The aim of this study was therefore to develop a LFG model for estimation of methane emissions from landfills in Lagos metropolis. Field investigations were carried out to determine waste composition, waste disposal rates and site conditions relevant for methane emissions estimation. Waste composition studies were conducted and waste fractions were divided into rapidly, moderately and slowly degrading. The output of the model was verified with the US EPA Landfill Gas Emission model (Land GEM). Results revealed maximum $\mathrm{CH}_{4}$ emissions estimated occurred at the end of landfill's closure. Methane generation potential $\left(L_{o}\right)$ and methane generation rate $(k)$ parameters were dependent on waste composition and site conditions. Model verification also showed methane emissions peaked at the end of landfill's closure for both models and variation in modelling parameters by Land GEM model resulted in significant change in methane emissions.
\end{abstract}

Keywords: Methane emissions, Landfills, Municipal solid waste, landfill gas, Land GEM model

\section{INTRODUCTION}

Urban population of the world has grown rapidly from 751 million in 1950 to 4.2 billion in 2018.Asia, despite its relatively lower level of urbanization, is home to $54 \%$ of the world's urban population followed by Europe and Africa at $13 \%$ each [1]. Waste volumes are expected to grow faster than the rate of urbanization with the volume increasing to 2.2 billion tonnes by 2025 [2]. Disposal of waste in landfill continues to be the most economically viable municipal solid waste (MSW) management practice in many countries in the world [3]. Landfill sites containing wastes undergoing biological decay typically emit high volumes of landfill gas (LFG). LFG mainly consists of $45 \%$ to $60 \%$ methane $\left(\mathrm{CH}_{4}\right), 40 \%$ to $60 \%$ carbon dioxide $\left(\mathrm{CO}_{2}\right)$ and small amounts of nitrogen, oxygen, ammonia, sulphides, carbon monoxide and non-methane organic compounds (NMOC) such as trichloroethylene, benzene and vinyl chloride [4]. Approximately $70 \%$ of $\mathrm{CH}_{4}$ emissions are anthropogenic and $19 \%$ of these are attributed to LFG generation [5].

The establishment of sustainable landfills is a key strategy in modern waste management concepts [6] and to evaluate appropriate methane reduction strategies, LFG production rates must be accurately quantified [7]. A large number of numerical and mathematical models have been developed to estimate LFG based on zero, first, and second-order approaches. However, zero and second-order models are not commonly used because the required parameters in each model are often so uncertain that

\footnotetext{
* Corresponding author, tel: $+234-703-056-7753$
} 
they negatively affect the accuracy of the model outcomes. Because of these limitations, simplified approaches have been developed based on first-order waste decay (FOD). The FOD models widely used by industry and state regulators are the Intergovernmental Panel on Climate Change (IPCC) and the United States Environmental Protection Agency Landfill Gas Emission Model (US EPA Land GEM) [3]. Most of these models are based on two primary model parameters, an ultimate methane generation potential $\left(L_{o}\right)$ and a first-order decay rate constant $(k)$. Estimation of these parameters is challenging because they are affected by many factors including, among others, the amount of waste disposed, waste composition, moisture content, temperature, and lag time in gas generation [8]. Current landfill gas generation models are typically overly simplified, not accounting for landfill-specific variations in waste composition, moisture content, and ambient temperature, which can significantly impact methane generation rates [9]. For instance, the widely used Land GEM has $k$ and $L_{o}$ values fixed over the entire life of a landfill. It doesn't accommodate changing landfill conditions such as variation in waste composition, climatic conditions and applications of liquid to existing waste. A number of international LFG models have been developed for countries such as Mexico, Ecuador, China, Ukraine and Columbia under the US EPA Landfill Methane Outreach Program (LMOP).These models are based on the Land GEM FOD and have model parameters $k$ and $L o$ dependent on the climatic conditions and landfill site conditions of these countries.

Waste generated in Lagos state increases with population and industrial development, with about 13,000 metric tonnes of municipal solid waste (MSW) generated daily. Wastes are collected and disposed at non-engineered landfills located at Ikeja (Olushosun) and Alimosho (Abule Egba and Solous) local government area respectively [10]. These sites lack adequate design consideration and have technical and operational problems, thereby functioning as dumps for municipal, healthcare and industrial waste materials [11]. Release of LFG has led to greenhouse gas (GHG) emissions and fire outbreaks due to open burning of refuse. Accurate prediction of LFG volumes in these landfills is needed in order to reduce modelling errors as well as under/over estimation of LFG recovery systems. Literature information is scarce on availability of LFG models for the estimation of $\mathrm{CH}_{4}$ generation in Lagos landfills. The aim of this research is therefore to develop a LFG model for the estimation of $\mathrm{CH}_{4}$ generation in landfills in Lagos Metropolis.

\section{METHODOLOGY}

\subsection{Model Development}

The model estimates $\mathrm{CH}_{4}$ generation based on FOD methodology in Land GEM model [12]. The model parameters $k$ and $L_{o}$ were modified using the IPCC methodology [13]. The modified equation is described in Equation 1:

$Q_{C H_{4}}=\sum_{i=1}^{n} \sum_{j=0.1}^{1} k L_{o}\left[\frac{M_{i}}{10}\right] e^{-k t_{i, j}}(F D F)$

where

$Q_{\mathrm{CH}_{4}}=$ estimated methane generation rate $\left(\mathrm{m}^{3} / \mathrm{yr}\right)$

$i=1$ year time increment

$n=$ (year of calculation) - (initial year of waste acceptance)

$j=0.1$ year time increment

$k=$ methane generation rate constant $\left(\mathrm{yr}^{-1}\right)$,

$L_{o}=$ methane generation potential of waste disposed ( $\mathrm{m}^{3} /$ tonne)

$M_{i}=$ solid waste disposed in the year $i^{\text {th }}$ year (tonnes)

$t_{i, j}=$ age of the $j^{\text {th }}$ section of waste disposed in the $i^{\text {th }}$ year (decimal years)

$F D F=$ fire discount factor

In order to avoid the use of excessive Excel worksheets as applicable in Land GEM model and allow flexibility in varying model parameters $L_{o}$ and $k$. The new model was developed with MATLAB Applications. The model allows the user input respective waste composition, waste depth, waste temperature, waste disposal rate and fire discount factor applicable to individual landfill.

\subsection{Methane generation potential $\left(L_{o}\right)$}

This describes the total amount of $\mathrm{CH}_{4}$ potentially produced by a metric tonne of waste as it decays. $\mathrm{CH}_{4}$ generation was calculated by IPCC methodology [13] as shown in Equation 2:

$$
L_{o}=D O C \times D O C_{f} \times M C F \times F \times 16 / 12
$$

DOC: is the organic carbon in waste that is accessible to biochemical decomposition. DOC values for various waste components [13] are shown in Table 1. This is multiplied by the percentage of the waste fraction in MSW.

Table 1: DOC content for different MSW components 


\begin{tabular}{llc}
\hline S/N & Waste components & $\begin{array}{c}\text { DOC content } \\
\text { in (\%) of wet } \\
\text { waste }\end{array}$ \\
\hline A & Paper and textile & 0.4 \\
B & Garden and park & 0.17 \\
C & Food waste & 0.15 \\
D & Wood & 0.30 \\
E & Plastics, Metal, Glass and & 0 \\
\hline \multicolumn{2}{c}{ Other inert materials } \\
\hline \multicolumn{2}{c}{ Source [13] }
\end{tabular}

Table 2: MCF values for various landfill sites

\begin{tabular}{lll}
\hline Landfill site & $\begin{array}{l}\text { Depth } \\
<5 \mathrm{~m}\end{array}$ & $\begin{array}{l}\text { Depth } \\
\geq 5 \mathrm{~m}\end{array}$ \\
\hline Without management & 0.4 & 0.8 \\
With management & 0.8 & 1.0 \\
Semi aerobic & 0.4 & 0.5 \\
Condition unknown & 0.4 & 0.8 \\
\hline \multicolumn{2}{c}{ Source [13] } \\
F
\end{tabular}

$D O C_{f}$ : This is an estimate of the fraction of carbon that is ultimately degraded and released from solid waste disposal sites (SWDS), it reflects the fact that some degradable organic carbon do not degrade, or degrades very slowly, under anaerobic conditions in the SWDS. This depends on the temperature in the anaerobic zone of the landfill site $[14,15]$. The $D O C_{f}$ is expressed in Equation 3

$$
D O C_{f}=0.014 T+0.28
$$

where $\mathrm{T}$ is temperature in the anaerobic zone in ${ }^{\circ} \mathrm{C}$. If unavailable by the user, a default value of $35^{\circ} \mathrm{C}$ was used. At $35^{\circ} \mathrm{C}$, almost $80 \%$ of the DOC would have been converted to LFG [14].

MCF: This is the methane correction factor which takes into account aerobic waste decay that does not produce $\mathrm{CH}_{4}$ at waste disposal sites [13]. It depends on the depth of a landfill and ranges from $0.4-1.0$ (Table 2).

$F$ : This is the fraction of $\mathrm{CH}_{4}$ in LFG $[13,15]$.A value of $50 \%$ was adopted.

\subsection{Methane generation rate constant $(k)$}

This describes the time taken for the $D O C$ in waste to decay to half its initial mass. It is called half-life and denoted by $k$. The rate at which $\mathrm{CH}_{4}$ emissions are generated from decaying material in a landfill depends upon: (1) the waste type (organic material placed in the landfill), and (2) the moisture conditions of the landfill (estimated based on average annual precipitation). The waste fractions were divided into three waste categories based on their rate of decay as: rapidly-degrading waste, slowly degrading waste and moderately degrading waste. These three waste categories were assigned different $k$ values to reflect their differences in waste decay rates based on their climatic conditions (Table 3). The $k$ value used in the model was then calculated by multiplying the different $k$ values by the quantity of the waste category in the waste stream and an overall $k$ value for a mixed municipal solid waste was gotten.

\subsection{Fire Discount Factor (FDF)}

The model also introduced the fire discount factor (FDF) in order to account for occurrence of landfill fires. For landfills where current or past landfill fires have been observed or are likely present, a reduction of 20 to $40 \%$ in the methane estimate might occur as the combined result of loss of organics and damaged collection system. For landfills where current or past landfill fires have been observed, fire discount factor is set at $30 \%$ [16].

Table 3: Methane generation rate constant for different wastes

\begin{tabular}{|c|c|c|c|c|c|}
\hline \multirow{3}{*}{$\mathrm{S} / \mathrm{N}$} & \multirow{3}{*}{ Type of waste } & \multicolumn{4}{|c|}{ Decay Rates $(k)$} \\
\hline & & \multicolumn{2}{|c|}{ Dry } & \multicolumn{2}{|l|}{ Moist and Wet } \\
\hline & & $\mathrm{MAT}<20^{\circ} \mathrm{C}$ & MAT $>20^{\circ} \mathrm{C}$ & $\mathrm{MAT}<20^{\circ} \mathrm{C}$ & MAT $>20^{\circ} \mathrm{C}$ \\
\hline \multirow{2}{*}{1} & Rapidly degrading waste (food & $0.05-0.08$ & $0.07-0.10$ & $0.10-0.20$ & $0.17-0.70$ \\
\hline & waste) & Default:0.06 & Default:0.085 & Default:0.185 & Default:0.4 \\
\hline \multirow{2}{*}{2} & Moderately degrading waste & $0.04-0.06$ & $0.05-0.08$ & $0.06-0.10$ & $0.15-0.20$ \\
\hline & (garden + park $)$ & Default:0.05 & Default:0.065 & Default:0.1 & Default:0.17 \\
\hline \multirow{4}{*}{3} & Slowly degrading waste (paper+ & $0.03-0.05$ & 0.04-0.06 & $0.05-0.07$ & $0.06-0.085$ \\
\hline & textiles) & Default:0.04 & Default:0.045 & Default:0.06 & Default:0.07 \\
\hline & Slowly degrading waste (wood & $0.01-0.03$ & $0.02-0.04$ & $0.02-0.04$ & $0.03-0.05$ \\
\hline & and straw) & Default:0.02 & Default:0.03 & Default:0.025 & Default:0.035 \\
\hline
\end{tabular}




\subsection{Description of Study Area}

Olushosun Landfill: It is the largest landfill in the state and is situated about $10 \mathrm{~km}$ South East of Ikeja Local Government Area, and located between 6059'11.11N 3038'13.89E [17]. It was established in 1992 with a lifespan of 35 years from the date of its establishment. It received an average of $1,000,000$ tonnes of waste annually [18]. The landfill was recently closed in June, 2018 due to fire incidence. The climate of the landfill location is similar to Lagos metropolis climate and is characterized by rainy and dry seasons. The monthly mean temperatures of the landfill ranged from $25.2^{\circ} \mathrm{C}-28.6^{\circ} \mathrm{C}$. The temperature is highest in March, at $28.6^{\circ} \mathrm{C}$ and lowest in August at $25.2^{\circ} \mathrm{C}$. Average precipitation also ranged from 21 $\mathrm{mm}-386 \mathrm{~mm}$. The least amount of rainfall occurs in December at about $21 \mathrm{~mm}$ while the greatest amount of precipitation occurs in June, with an average of $386 \mathrm{~mm}$. The average annual precipitation is 1693 $\mathrm{mm}$ [19].

\subsection{Waste disposal rate}

Waste disposal in Olushosun landfill started in 1992 till March, 2018 when it was closed by the Lagos State government due to the fire incidence. The landfill received approximately $40 \%$ of the total waste deposits in Lagos state [20]. Waste deposited in the landfill consisted of unprocessed wastes of all types, ranging from organic to inorganic and hazardous to non-hazardous wastes. The quantity of waste deposited in the landfill had been on the increase due to rapid population growth and urbanization. Waste deposited in the landfill increased from 165,909 metric tonnes in 1992 to 880,866 metric tonnes in 2017. A total of $11,066,908$ metric tonnes of wastes was deposited in the landfill at the time of closure (Table 4).

\subsection{Waste composition}

Sampling of wastes was carried out at Olushosun landfill in the dry and wet seasons (April, 2015 and July 2016) according to American Society of Testing and Materials (ASTM-D5231-92)[21]. The duration of the studies and sample sizes were different for the two seasons due to the on-going renovation at the site at the time of investigation. In the dry season, a total of 40 trucks were sampled for a period of 6 days while 74 trucks were sampled for 14 days during the wet season. Bags of wastes of about $200 \mathrm{~kg}$ were picked randomly from each compactor trucks tipping at the site during both seasons, the sampled wastes were placed on a mat, opened and remixed until a representative sample of $100 \mathrm{~kg}$ was obtained. Characterization of the waste samples followed a procedure described by [22].

\section{RESULTS AND DISCUSSION}

\subsection{Waste composition studies}

The results of the waste composition studies showed that waste collected in Lagos metropolis and deposited in Olushosun landfill contained about 50\% food waste while $45 \%$ were recyclable waste (Figure $6)$.

Table 4: Waste disposal rate in Olushosun landfill

\begin{tabular}{cccccc}
\hline Year & $\begin{array}{c}\text { Waste deposited } \\
\text { (metric tons) }\end{array}$ & $\begin{array}{c}\text { Cumulative waste } \\
\text { deposited (tons) }\end{array}$ & Year & $\begin{array}{c}\text { Waste } \\
\text { deposited } \\
\text { (metric tons) }\end{array}$ & $\begin{array}{c}\text { Cumulative waste } \\
\text { deposited (tons) }\end{array}$ \\
\hline 1992 & 165909 & 165,909 & 2005 & 312846 & $3,251,584$ \\
1993 & 174204 & 340,113 & 2006 & 328489 & $3,580,073$ \\
1994 & 182914 & 523,027 & 2007 & 344912 & $3,924,985$ \\
1995 & 192060 & 715,087 & 2008 & 567814 & $4,492,799$ \\
1996 & 201663 & 916,750 & 2009 & 596205 & $5,089,004$ \\
1997 & 211746 & $1,128,496$ & 2010 & 626015 & $5,715,019$ \\
1998 & 222333 & $1,350,829$ & 2011 & 657316 & $6,372,335$ \\
1999 & 233450 & $1,584,279$ & 2012 & 690181 & $7,062,516$ \\
2000 & 245123 & $1,829,402$ & 2013 & 724690 & $7,787,206$ \\
2001 & 257379 & $2,086,781$ & 2014 & 760925 & $8,548,131$ \\
2002 & 270248 & $2,357,029$ & 2015 & 798971 & $9,347,102$ \\
2003 & 283760 & $2,640,789$ & 2016 & 838920 & $10,186,022$ \\
2004 & 297949 & $2,938,738$ & 2017 & 880866 & $11,066,908$ \\
\hline
\end{tabular}

Source [10] 
This is also confirmed by various waste composition studies conducted in the state (Table 5) which indicated that solid waste generated is mostly organic consisting of food waste [22-24]. The proportion of some of the recyclable fractions was relatively small (such as metals - $4 \%$, glass - $2 \%$ and plastics - $7 \%$ ). This was a result of scavenging activities being undertaken at the disposal site.

Waste composition studies in Lagos State from previous years were collated, and the average was established. (see Table 5). This was used in the determination of $k$ and $L_{o}$ values used in the estimation of methane emissions.

\subsection{Methane emissions estimation from Olushosun landfill}

Estimation of methane emissions for Olushosun landfill was done for the period 1992-2020.The following data was used to estimate methane emissions:

- $D O C$ value was found to be 0.19 based on the waste composition of MSW deposited in the landfill

- $\quad D O C_{f}$ was found to be 0.77 by assuming a landfill temperature of $35^{\circ} \mathrm{C}$

- MCF for Olushosun landfill was 0.8 as this satisfied the criteria of an unmanaged deep landfill

- FDF was $30 \%$ due to open burning of refuse that had been practiced

Based on the estimation of different parameters, $L_{o}$ of $76.36 \mathrm{~m}^{3} /$ ton was derived for Olushosun landfill.

This value is within the range of $6-270 \mathrm{~m}^{3} /$ ton specified by US EPA, but $L_{o}$ varies across different landfills in different countries [8]. $L_{o}$ values of $90-$
$128 \mathrm{~m}^{3} /$ ton was recorded for 35 Canadian Landfills with the use of European Pollutant Emission Register (EPER), Netherlands Organisation of Applied Scientific Research (TNO), Zero-order, Scholl Canyon and LandGEM version 2.01 models [7]. Results from [25] also indicated $L_{o}$ value of $43.01 \mathrm{~m}^{3} /$ tonne at Awotan and Lapite dumpsites in Ibadan, Nigeria. This value was lower than methane generation potential for Olushosun landfill due to low organic waste deposited. $L_{o}$ value depends almost exclusively on the waste composition and it is a function of the organic content of the waste. The higher the organic content of the waste, the higher the $L_{o}$ [26].

In order to estimate $k$ value for the landfill, the suggested default values of $k$ for different waste categories for a wet landfill at temperature greater than $20^{\circ} \mathrm{C}$ was used. $k$ value of $0.24 \mathrm{yr}^{-1}$ was derived for Olushosun landfill.

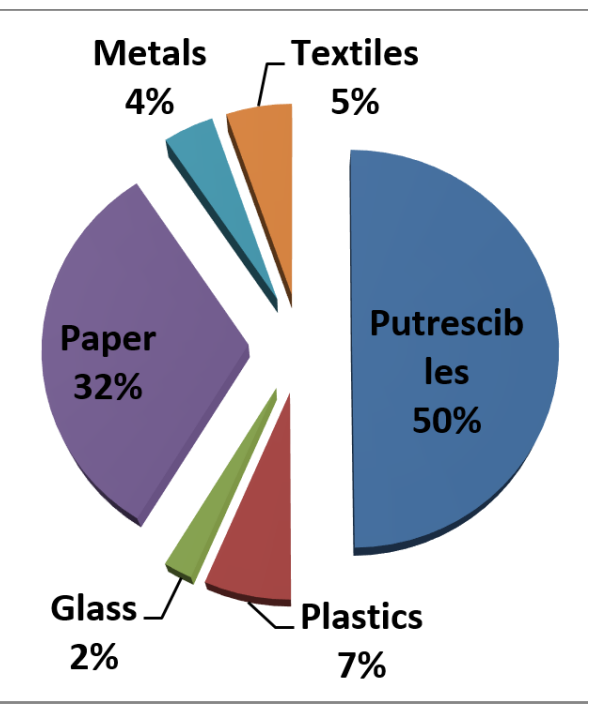

Figure 1: Composition of MSW generated in Olushosun landfill

Table 5: Waste composition studies in Lagos Metropolis

\begin{tabular}{cccccc}
\hline $\begin{array}{c}\text { Waste composition } \\
(\%)\end{array}$ & $\begin{array}{c}\text { Longe and } \\
\text { Ukpebor (2009) }\end{array}$ & $\begin{array}{c}\text { Ogwueleka } \\
(2009)\end{array}$ & $\begin{array}{c}\text { Oyelola and } \\
\text { Babatunde (2010) }\end{array}$ & $\begin{array}{c}\text { Present } \\
\text { study }\end{array}$ & Average \\
\hline Putrescibles & 41.8 & 56 & 68.57 & 50.88 & 54.31 \\
Plastics & 7.8 & 4 & 2.71 & 6.72 & 5.30 \\
Glass & 9 & 3 & 1.78 & 2.25 & 4.00 \\
Paper & 16 & 14 & 16.95 & 32.48 & 19.85 \\
Metals & 7.4 & 4 & 2.97 & 4.2 & 4.64 \\
Garden & 0 & 0 & 4.20 & 0 & 4.20 \\
Textiles & 5.1 & 4 & 0 & 0 & 4.55 \\
Others & 12.8 & 15 & 0 & 0 & 13.9 \\
\hline Total & 100 & 100 & 100 & 100 & 100 \\
\hline
\end{tabular}


Table 6: LandGEM default modelling parameters

\begin{tabular}{lllll}
\hline \multirow{2}{*}{ Landfill site } & \multicolumn{3}{c}{$k\left(\right.$ year $\left.^{-1}\right)$} & \multicolumn{2}{c}{$L_{o}\left(\mathrm{~m}^{3} /\right.$ tonne $)$} \\
\cline { 2 - 5 } & CAA & Inventory & CAA & Inventory \\
\hline Conventional/Sanitary & 0.05 & 0.04 & 170 & 100 \\
Arid Area & 0.02 & 0.02 & 170 & 100 \\
Wet (Bioreactor) & --- & 0.70 & ---- & 96 \\
\hline
\end{tabular}

Source [12]

This is similar to $k$ value of $0.235 \mathrm{yr}^{-1}$ obtained for India landfill due to the high percentage of food waste recorded in their waste stream [27]. In other studies, $k$ values reported varied from $0.04-0.09 \mathrm{yr}^{-1}$ for US landfills [3], 0.023-0.056 $\mathrm{yr}^{-1}$ for Canadian landfills [7] and $0.0429 \mathrm{yr}^{-1}$ for Mexico landfills [28].

Applying the model parameters of $L_{o}=76.36$ $\mathrm{m}^{3} /$ tonne and $k=0.24 \mathrm{yr}^{-1}$ for the landfill sites, $\mathrm{CH}_{4}$ emissions estimated increased from $831,957 \mathrm{~m}^{3} / \mathrm{yr}$ in 1993 until it attained maximum value of 17,179, 275 $\mathrm{m}^{3} / \mathrm{yr}$ in 2018. The total $\mathrm{CH}_{4}$ emissions generated from $1992-2020$ was $219,886,140 \mathrm{~m}^{3} / \mathrm{yr}$ (Figure 2).

\subsection{Model validation}

The model validation was done by comparing the output of the new model with the LandGEM model. There are two sets of modeling parameters proposed in LandGEM for different types of landfills; sanitary, Arid and Bioreactor landfills. (Table 6): LandGEM Clean Air Act (CAA) and inventory modeling parameters for sanitary landfills was used.

The maximum $\mathrm{CH}_{4}$ generation estimated from LandGEM CAA and LandGEM inventory for Olushosun landfill are $63,530,000 \mathrm{~m}^{3} / \mathrm{yr}$ and $32,080,000 \mathrm{~m}^{3} / \mathrm{yr}$ respectively. This occurred in 2018 at the of landfill's closure. This values are higher than the maximum $\mathrm{CH}_{4}$ generation value $\left(17,179,275 \mathrm{~m}^{3} / \mathrm{yr}\right)$ obtained from the new model. The major difference between the models is the calculation steps adopted for the methane gas generating potential $\left(L_{o}\right)$ and first order decay rate. The LandGEM model uses constant values for the $L_{o}$ and $k$ while the new model takes into account the site specific waste composition and landfill site conditions in its estimation.

\section{CONCLUSION}

The new LFG model developed was based on the widely accepted FOD reaction and the IPCC guidelines for the estimation of methane emissions. Methane generation potential $\left(L_{o}\right)$ was estimated based on actual waste composition, degradable organic carbon (DOC) and landfill site characteristics. The methane generation rate $(k)$ was calculated based on the decay rate of each individual waste component. Olushosun landfill was modelled with the new model and LandGEM model and the results were compared. Results revealed maximum $\mathrm{CH}_{4}$ emissions estimated occurred at the end of landfill's closure.

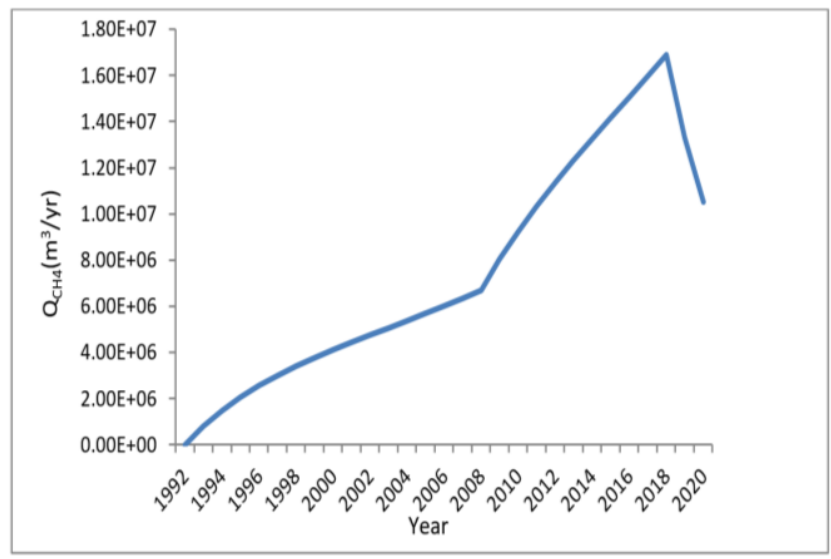

Figure 2: Methane generation in Olushosun landfill

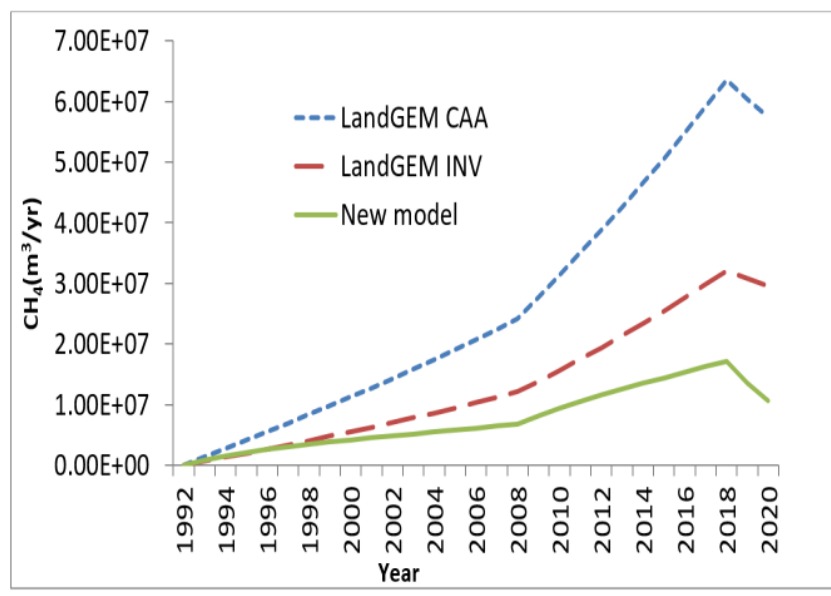

Figure 3: Methane generation in Olushosun landfill with LandGEM and the new model

Methane generation potential ( $\left.L_{o}\right)$ and methane generation rate $(k)$ parameters were dependent on waste composition and site conditions.Validation of the new model with LandGEM CAA and inventory model parameters showed similar output graph but with significant changes in methane generation. The new model is recommended for use by decision makers and landfill owners as it is simple to use and accommodates varying $k$ and $L_{o}$ during the landfill operations. 


\section{REFERENCES}

[1] United Nations Department of Economic and Social affairs (UN DESA). "2018 Revision of World Urbanization Prospects" https://www.un.org/development/.../publications 2018-revision-of-world-urbanization, Accessed on June 12, 2018

[2] Ripaldi, G. "Life cycle assessment of waste management system". The case of Avezzano, Italy. Master thesis, Industrial Ecology, Royal Institute of Technology, Stockholm, 2015.

[3] Amini, H. R., Reinhart, D. R. and Niskanen, A. "Comparison of first-order-decay modeled and actual field measured municipal solid waste landfill methane data" Waste Management, Vol. 33, pp 2720-2728, 2013.

[4] Agency for Toxic Substances and Disease Registry (ATSDR). "Landfill gas Primer-An Overview for Environmental Health Professionals". https://www.atsdr.cdc.gov/HAC/landfill/html/ch2. html.2001, Accessed October 15, 2017.

[5] Atabi, F., Ehyaei, M. A. and Ahmadi, M. H. "Calculation of $\mathrm{CH}_{4}$ and $\mathrm{CO}_{2}$ emission rate in Kahrizak landfill site with LandGEM mathematical model". Conference proceedings paper at the $4^{\text {th }}$ World Sustainability Forum, Switzerland, November 1-30, pp 1-17, 2014.

[6] Vaverkova, M. and Adamcova, D. "Long-term temperature monitoring of a municipal solid waste landfill". Polish Journal of Environmental Studies, Vol. 24, Number 3, pp 1373-1378, 2015.

[7] Thompson S., Sawyer J., Bonam R. and Valdivia J.E. "Building a better methane generation model: Validating models with methane recovery rates from 35 Canadian landfills". Waste Management, Vol.29, Number 7, pp 2085-2091, 2009.

[8] Amini, H. R. "Landfill gas to energy: Incentives and Benefits". Doctoral Theses, Department of Civil, Environmental and Construction Engineering, The University of Central Florida, Orlando, Florida, 2011.

[9] Karanjekar, R. V. "An improved for predicting methane emissions from landfills based on rainfall, ambient temperature and waste composition". Doctoral Thesis, Department of Civil Engineering, The University of Texas, Airlington, 2012.

[10] Opejin, A. K. "Assessment of the regenerative potential of organic waste streams in Lagos mega- city". Master Thesis, Department of Urban and Environmental Planning, Arizona State University, USA, 2016.

[11] Longe, E. O. and Enekwechi, L. O. "Investigation on potential groundwater impacts and influence of local hydrogeology on natural attenuation of leachate at a municipal landfill". International Journal of Environmental Science and Technology, Vol.4, Number 1, pp 133-140, 2007.

[12] United States Environmental Protection Agency (US EPA) 2005. "Landfill Gas Emissions Model (LandGEM) Version 3.02 User's Guide". https://www3.epa.gov/ttncatc1/dir1/landgemv302-guide.pdf, Accessed January 15, 2016.

[13]Intergovernmental Panel on Climate Change (IPCC) 2006. "2006 IPCC Guidelines for National Greenhouse Gas Inventories, Vol. 5. IGES, Hayama, $\quad$ http://www.ipccnggip.iges.or.jp/public/2006gl/vol5.html,

Accessed March 14, 2016.

[14] Bingemer H. G. and Crutzen P. J. "The production of methane from solid wastes". Journal of Geophysical Research, Vol. 92, Number D2, pp 2181-2187, 1987.

[15] Kumar, S., Gaikwad, S. A., Shekdar, A. V., Kshirsagar, P. S., and Singh, R. N. "Estimation method for national methane emission from solid waste landfills". Atmospheric Environment, Vol. 38, pp 3481-3487, 2004.

[16] Landfill Methane Outreach Program (LMOP) 2009. "User's Manual China Landfill Gas Model"https://www.globalmethane.org/document s/models/pdfs/UsersManualChinaLFGmodel v1.1eng.pdf, Accessed April 12, 2018.

[17] Nwambuonwo, O. J. and Mughele, E. S. "Using geographic information system to select suitable landfill sites for megacities (Case Study of Lagos, Nigeria)". Computing, Information Systems and Development Informatics, Vol. 3, Number 4,pp 4958, 2012.

[18] Olorunfemi, F. B. "Landfill development and current practices in Lagos metropolis, Nigeria". Journal of Geography and Regional Planning, Vol. 4, Number 12, pp 656-663, 2011.

[19] Climate-data. "Lagos climate". https://en.climatedata.org/location/552/\#temperature-graph, Accessed October 12, 2017.

[20]Lagos State Waste Management Authority (LAWMA). "Landfill management". 
http://www.lawma.gov.ng/insidelawma/departments/landfill/2017, November 15, 2018.

Accessed

[21] ASTMD 5231-92. "Standard Test Method for Determination of the Composition of Unprocessed Municipal Solid Waste", American Society for Testing and Materials, 2003.

[22] Longe, E. O. and Ukpebor, E. F. "Survey of household waste generation and composition in Ojo Local Government Area, Lagos State, Nigeria". International Journal of Geotechnics and Environment, Vol. 1, Number 1, pp 41-54, 2009.

[23] Ogwueleka, T. C. "Municipal solid waste characteristics and management in Nigeria". Iran Journal of Environment Health Science and Engineering, Vol. 6, Number 3, pp 173-180, 2009.

[24] Oyelola, O. T. and Babatunde, A. I. "Characterization of domestic and market solid waste at source in Lagos metropolis, Lagos, Nigeria". African Journal of Environmental and Waste Management, Vol. 1, Number 5, pp 085091, 2013.
[25] Akintayo, F. O. and Olonisakin, O. A. "Methane generation of municipal solid waste in Ibadan". Nigerian Journal of Technology, Vol. 33, Number 1, pp 49-53, 2014.

[26] Landfill Methane Outreach Program (LMOP). "Landfill Gas Energy project development handbook". $\quad$ https://www.epa.gov/sites/ production/files/2016-11/documents/ pdh full.pdf, Accessed March 5, 2017.

[27] Sil, A., Kumar. S., and Kumar, R. "Formulating LandGem model for estimation of landfill gas under Indian scenario". International Journal of Environmental Technology and Management, Vol. 17, pp 293-299, 2014.

[28] Machado, S. L., Carvalho, M. F., Gourc, J-P., Vilar, O. M., do Nascimento, J. C. F. "Methane generation in tropical landfills: simplified methods and field results". Waste Management, Vol. 29, pp 153-161, 2009. 